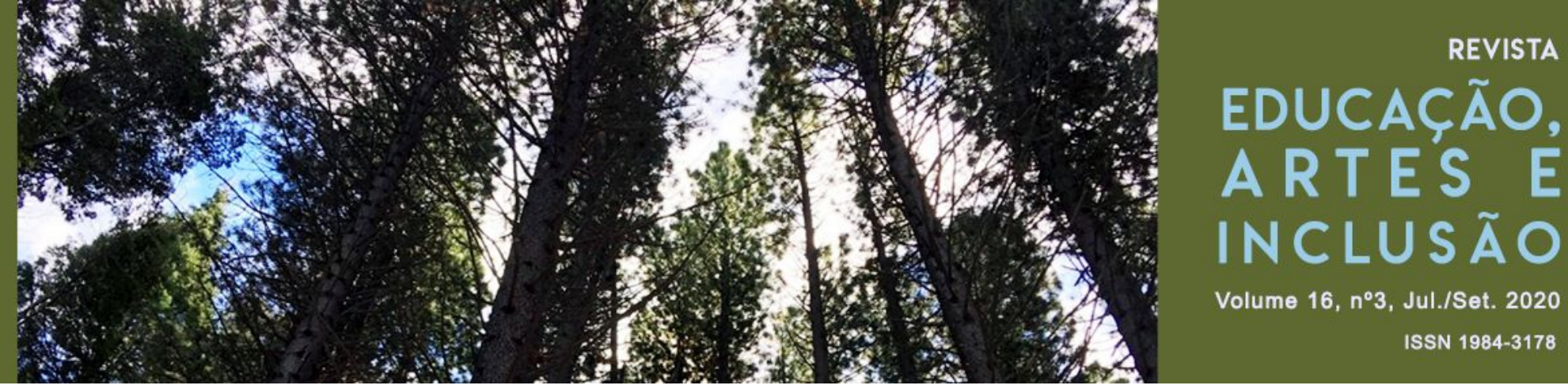

\title{
CROSS-CULTURAL NARRATIVE THROUGH GRAPHIC STORIES IN POLISARIO REFUGEE CAMPS
}

\section{A NARRATIVA TRANSCULTURAL POR MEIO DE NOVELAS GRÁFICAS NO CAMPO DE REFUGIADOS POLISARIO}

\author{
DOI: http://dx.doi.org/10.5965/198431781632020103
}

\author{
Rolf Laven \\ Universidade de Viena \\ rolf.laven@phwien.ac.at
}

\begin{abstract}
The Graphic Novel as a development of the last decades and nowadays an independent art form is presented in the context of workshop series within its educational potentials. Graphic story telling workshop series as methology exemplifies us an alternative form of communication beyond textual literacy. This took place within the framework of teacher training workshops in the Polisario refugee camps in Algeria. With the possibilities of the graphic novels, contents from the school environment and the everyday life of the participants were developed by means of art education, in the sense of a reflection of the own work event/ reference, for oneself and others. Drawings and personal stories from everyday life were developed in detail in the form of successive pictures and pictorial elements, sometimes including writing. In a non-verbal and playful way, the reality of life should come to face. In particular, one's own experiential space should be experienced as a source of creativity - personal, original, self-referential should be appreciated and valued. Unconventional forms of communication were generated and established as mutually effective educational methods.
\end{abstract}

Keywords: Visual Interaction; Graphic Storytelling; Saharawi Refugee Camps;

RESUMO: Uma novela gráfica, desenvolvida nas últimas décadas e agora como uma forma de arte independente, é o foco deste texto. A novela gráfica é aqui apresentada no contexto de uma série de workshops sobre o potencial educacional do formato. Uma série de workshops gráficos que conta histórias é apresentada como um exemplo, como uma forma alternativa de comunicação além da alfabetização textual. Isso ocorreu no âmbito de oficinas de formação de professores nos campos de refugiados de Polisario, na Argélia. Com as possibilidades das novelas gráficas, os conteúdos do ambiente escolar e do cotidiano dos participantes foram desenvolvidos por meio da arte/educação, no sentido de uma reflexão do próprio evento/referência de trabalho, para si e para os outros. Desenhos e histórias pessoais da vida cotidiana foram desenvolvidos em detalhes em imagens sucessivas e elementos pictóricos, às vezes incluindo a escrita. De uma maneira não verbal e lúdica, a realidade da vida deve vir à tona. Em particular, o próprio espaço experiencial deve ser experimentado como uma fonte de criatividade - pessoal, original e de autorreferência que deve ser apreciada e valorizada. Assim, formas não-convencionais de comunicação foram geradas e estabelecidas como métodos educacionais mutuamente eficazes.

Palavras-chave: Interação Visual Narrativa Gráfica; Campos de Refugiados Saharawi; 


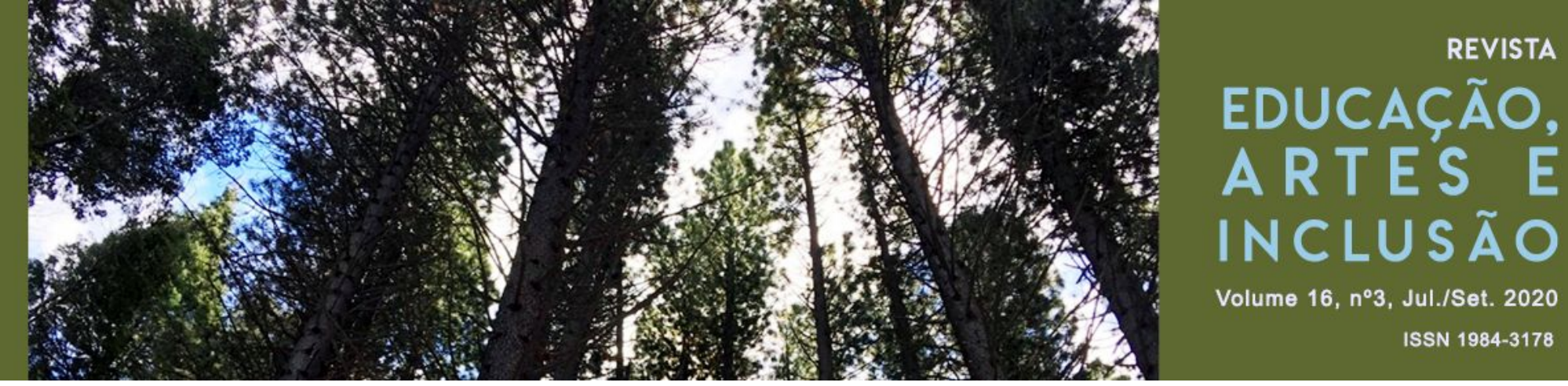

visual arts education, in the process reflecting upon their own work experiences as well as the relationships between themselves and others. Participants came up with their own stories about their daily professional routines and developed them in detail in the form of sequences of images with occasional supplemental writing. Through nonverbal and playful means, the partakers certainties were developed in pictures. One's own field of experience was used as a source for creative output, underling the notion that one's own original and personal experience should receive the strongest possible appreciation.

Self-created stories from day-to-day business were developed in detail in the form of successive pictures and picture elements, partly by incorporating writing. In non-verbal and playful ways, life-reality should come to the fore. In particular, one's own area of experience should be experienced as a source of creativity - personal, original, self-referential should be valued. Alternative forms of communication possibilities were created and received as mutually effective educational processes.

\section{THE POLITICAL SITUATION BACKGROUND}

Large parts of Western Sahara have been occupied by Morocco for more than two generations without interruption (UNO RESOLUTION, 2018). By means of a more than $2500 \mathrm{~km}$ long, mined earth or stone wall, which the state of Morocco has built since the occupation in 1975, the refugees were excluded from their ancestral territories near the sea into the distant desert of Algeria. This is an internationally almost forgotten drama in world history (FENNINGER, 2001, p. 14).

190,000 Saharaouis, inhabitants of the former Spanish colony of Western Sahara, have been living for almost 45 years in the refugee camps near the Algerian military city Tindūf, in an area of the Sahara characterised by sandy winds (UNO RESOLUTION, 2018). 


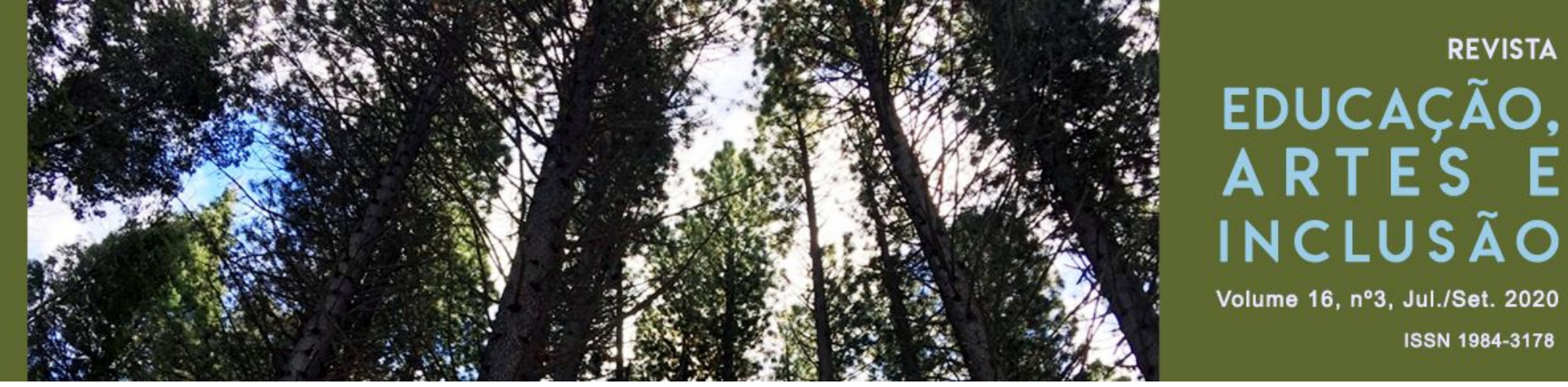

\section{THE LOCAL LIVING SITUATION IN THE CAMPS}

The camps of the Sahrawi refugees in the south of Algeria are in the most desertic of all deserts. It is a vast emptiness, surrounded by nothingness, where only rocks grow. And yet in this place, and in the liberated areas, which are not much better, the Saharawis have been able to construct the most open and the least machista society in the entire Muslim world.

This miracle of the Saharawis, who are very poor and very few, cannot be explained solely by their tenacious will to be free, which is abundant in these places where everything is lacking. It is also largely a factor of international solidarity. And the majority of assistance comes from the people of Spain. Their vital solidarity, memory and dignity are far more powerful than the waffling of governments and the cynical calculations of business ${ }^{1}$. They are called children of the clouds because they have always chased the rain (GALEANO, 2015).

The camps of the Sahrawi refugees in the south of Algeria are located in the most inhospitable of deserts. It is vast emptiness, surrounded by emptiness. (...)The Sahraouis are waiting. For thirty years now they have been searching for justice, which in today's world seems even rarer than "water in the desert. (GALEANO, 2006).

\section{GOALS}

The research activities in the refugee camps of the Polisario took place atop the cultural foundation of the predominantly Muslim Saharawi, one that is primarily characterized by textual literacy. For these teachers, the realizing of visual images as a means of communication was a method that they had never previously encountered and was learned as a new educational approach. The focus rested on the role of visual expression in the process of personal, internal and broader, external appropriation. The resulting illustrated worlds thus illuminated the teacher's

\footnotetext{
${ }^{1}$ Solidarity, not charity. Charity humiliates. Do not forget the African proverb: "The hand that receives is always lower than the hand that gives". The Saharawis wait. They are condemned to perpetual anguish and perpetual nostalgia. The refugee camps carry the names of their kidnapped cities, their lost meeting places, their haunts: L'ayoun, Smara, Dakhla.
} 


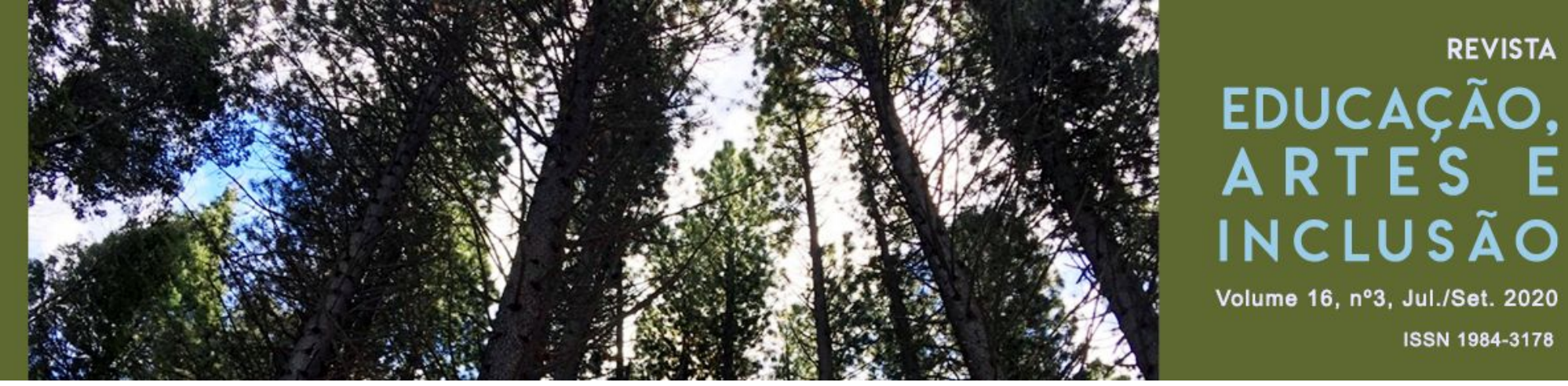

perspectives and worldviews. Artists negotiated everyday experiences with imagined material and implemented their vision through graphic means. The presentation, illustrative representation, and reception of the works were experienced at the intersection of teaching and learning processes at mutually effective meta-levels for the participants. Methods included participatory observation, qualitative empirical investigation, and phenomenological analysis (MAROTZKI and STOETZER, 2006).

The children's drawings demonstrated the conditions of original documents; complexity and focus were not limited to narrative content. The given topic and the resulting visual representations favoured the reorganization of the job profiles and the living and working environment in the refugee camps in the Algerian Hamada. A holistic approach was taken to uncovering the individual personalities of the teachers, whereby the focus was not on their weaknesses but rather their competences, interests, and social strengths, all of which were significantly explored and supported.

This approach can be described by the term 'empowerment' which is based on ensuring the appreciation of the participants (HERRIGER, 2014). It identifies processes in which people work out their own affairs and become aware of their individual strengths and abilities, thus gaining self-knowledge. In a setting that fosters coexistence, participation, and creativity, social resources could also be developed that become available for reference in the future. As theorized by Hannah Arendt (1970/1993), the "power to create" is understood as a "power and ability": "Power springs from the human ability not only to act or to do something, but to unite with others and in agreement to act with them." (ARENDT, 1970, p. 45).

\section{THE PROJECT AND ITS CONDITIONS}

Rolf Laven (Vienna University of Education) conducted three research stays in the Algerian refugee camps of Western Sahara from February 2015 to November 2017, where he conducted teaching hospitations/work shadowings, workshops and qualitative-empirical investigations in the medium of children's drawings as a creative 


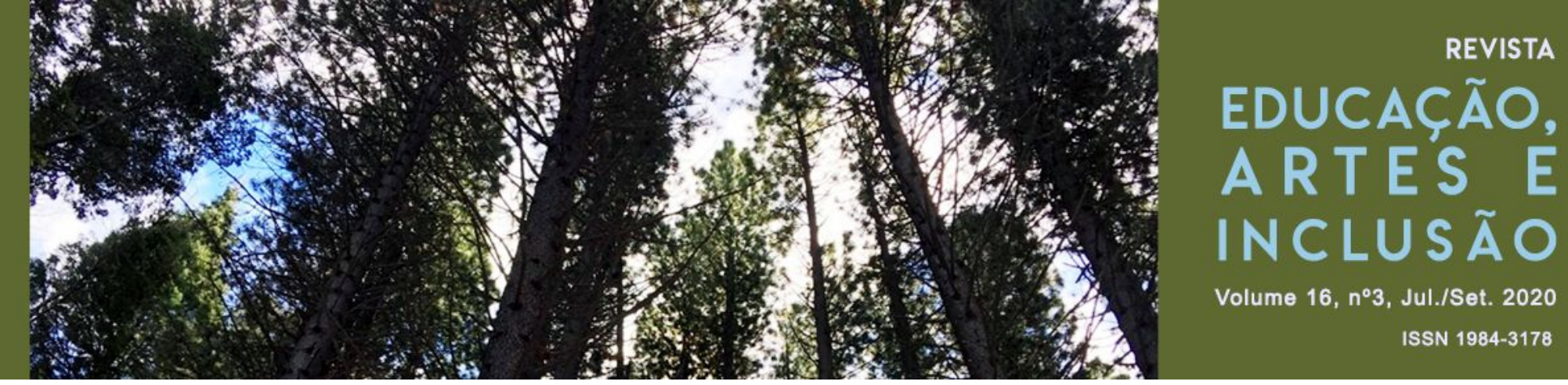

Which art educational approaches can create communication - even across language barriers? These guiding questions determine the procedure. In order to be able to approach the questions and answers, the Saharawi teachers, accompanied by Rolf Laven, implemented Graphic Story Telling-Workshops. The aim of these workshops was to communicate via visual language and imagination.

The aim is to make the creative expressions of inhabitants in camps in the Algerian Hamada comprehensible and to give an insight into the lives of refugees. Information about visual languages and living environments is to be generated in order to make it usable for future art education in the age of globalization in our transcultural societies (WELSCH, 2012, p. 146-156). The intended approach is to achieve equal rights with the project partners on an equal footing and to offer a platform to emancipatively face the challenges of reality.

"Those affected by the research are [...] not test persons, objects, but partners, subjects (Die von der Forschung Betroffenen sind [...] nicht Versuchspersonen, Objekte, sondern Partner, Subjekte)" (MAYRING, 2002, p. 50). In this sense, efforts were made to achieve an "exchange on equal terms and free of domination (gleichberechtigten und herrschaftsfreien Austausch)" (MAYRING, 2002, p. 50). As Jutta Ströter-Bender and Heidrun Wolter (2005) emphasize, it is a matter of breaking up Eurocentric structures of perception in order to evoke further-reaching (transcultural) competencies - on the part of the researchers. They point out that in cultures, in addition to art, architecture and everyday consumer goods, an immaterial legacy of intellectual traditions and manifest realizations, which has yet to be discovered, is transmitted. The awareness and transmission of this legacy means that the cultural heritage has to be integrated into the reality of life of those affected (STRÖTER-BENDER, 2002, p. 09).

Within the framework of the field research, the author lived with the families on site and was thus able to reconstruct the life-world references. The participating observation (MAYRING, 2002) referred - besides the experience of educational and 


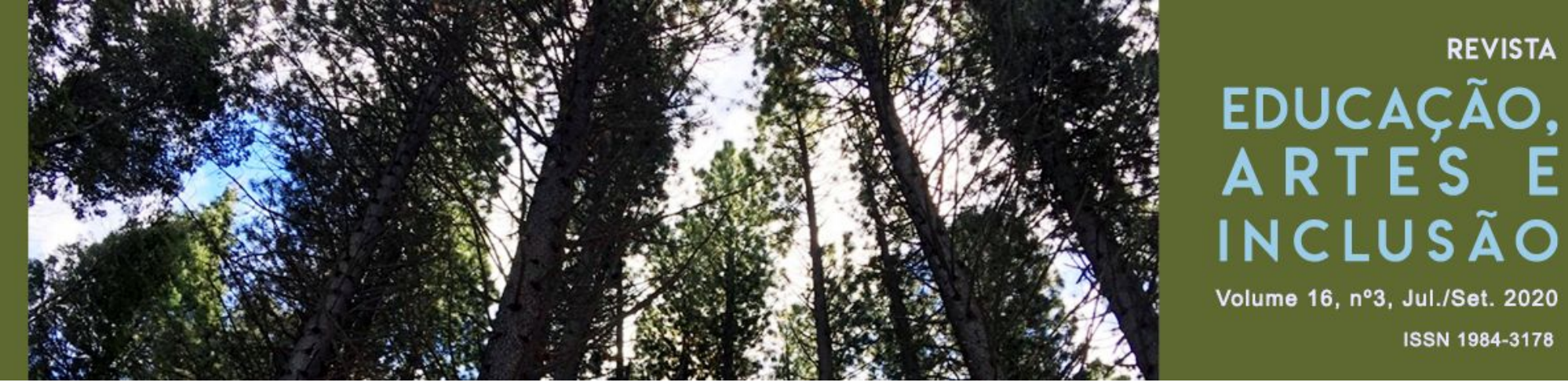

organizational settings - also to the communication potentials around the drawings. In the qualitative analysis, a structuring approach was taken (MAYRING, 2002), sifting according to determining criteria. The work assignment in the four camps, which were located at a distance from each other, was the same and very open: 'Draw what you touched with your hands (on that day)! This suggestion was ostensibly aimed at resource orientation and at the same time made it possible to deal with the situation in a situation-oriented manner. Resource orientation means: 'Draw objects that are important to you, that are pleasant, interesting or important to you'. This included the depiction of situation-dependent constellations, e.g. family situations, the way to school, a journey or an experience.

\section{PROCEDURE AND PRACTICAL IMPLEMENTATION OF DRAWING WORKSHOPS}

The workshop series was overall part of the cooperative project targeting the subjects of personal competency and implementing interdisciplinary (communicative) methods in the teaching profession.

The idea of communicating with teachers about their everyday teaching life through drawings initially arose after inspiring visits to the schools located at the refugee camps in the Western Sahara located near Tindūf, Algeria. Due to the pronounced differences in the culture's school and social systems, it was not assumed that there had been any previous engagement with the graphic or illustrated novel, or that participants would have an individualized drawing style.

First, individual graphic expression was defined, actualized and practically developed into a drawn manuscript. The respective teacher-student image was agreed upon as a topic.

There are many different approaches to the task, including rough sketching, developing a narrative story, collecting ideas onto a page, creating a sketchbook, or writing a script. With the creation of a visualized story from one imagined, it became 


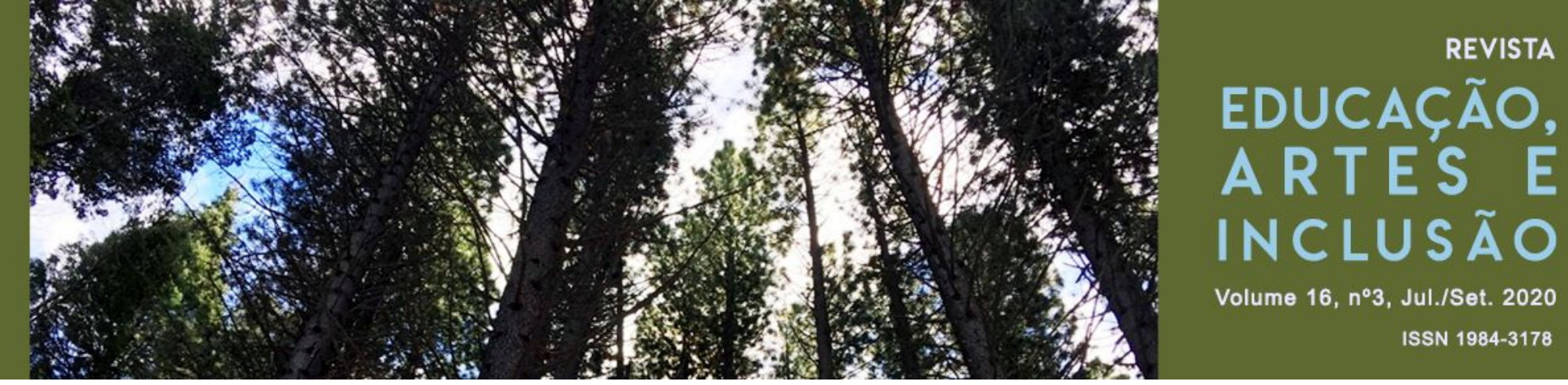

increasingly easier for the illustrators to create their characters. This came from outlining initial ideas through targeted preliminary markers and signs. On this basis, teachers visualized their characters and/or heroes and, in the end, made their drawings using lead and ink in a multi-step process that worked in conjunction with creating a scripted narrative. There were no restrictions with regard to form, colour, or language, and every graphic was a creative form of expression that was directly integrated. No previous time was used for practice, and as such, each first draft was central to the development of the drawing's core. A variety of drawing materials were offered, including coloured pencils, pastel and wax crayons, black felttip pens, fineliner pens, and markers.

Participants made numerous decisions in regards to choice of paper, composition, content, portrait or landscape format, and proportionality. The entire page was drawn using pencil. The participants would make either precise or vague sketches, and the text for each panel could be entered directly onto the page using pencil. As soon as the participants felt satisfied with their pencil drafts, they would begin the next phase of the process, which involved using ink of various weights, such as black felt-tip pens, fineliner pens, and markers. The option to use Chinese ink, which is optimal for creating deep, vivid, and powerful images using a brush, was eliminated due to time constraints as well as the lack of sensible prior experience with its use.

The panels for the introduction of the script - as well as the texts in Arabic calligraphy - were traced using fineliner pens. It was possible to later colorize the drawing using coloured pencils, and pastel and wax crayons. Unnecessary pencil lines were erased near the conclusion, and small corrections could be made by partially scraping out material using Stanley knives. Operating with erasers or white correction colours, this would have changed the quality of the drawings and added dimension to the paper, and also would have interfered with the immediacy and directness of the illustration. This directness remained evident in the work of the 


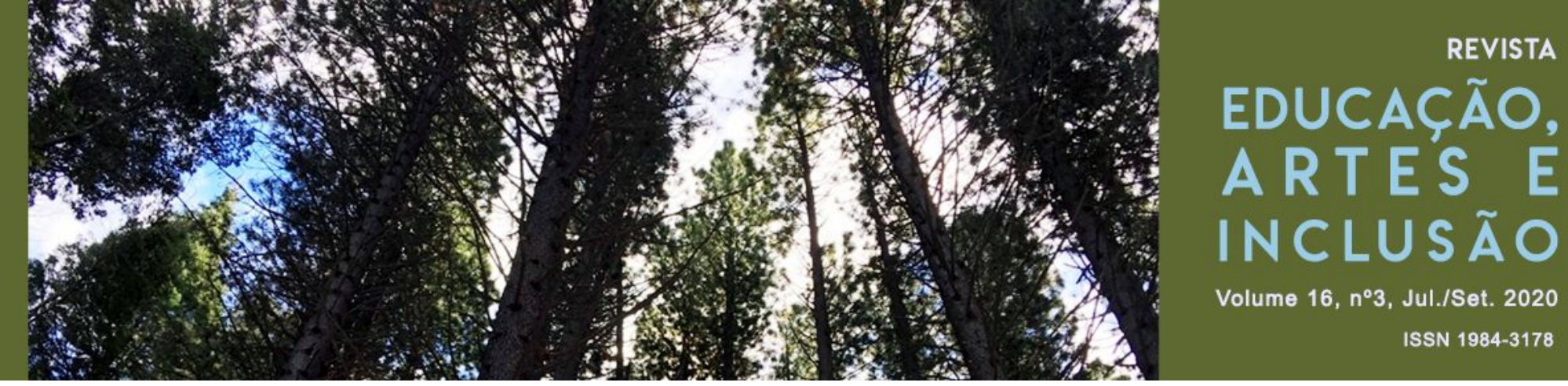

participants. Using various means of artistic expression, such as colour, shade, line widths, and layout, precise atmospheric images and visual worlds were produced in an expressive manner, such to the extent that in some cases, participants deliberately chose to not include any textual input.

\section{THE DRAWING OF THE GRAPHIC STORY TELLING}

In order to achieve the goal, namely to gain more information about people's living environments and conditions and modes of expression under the circumstances described above, as well as about the potential of communicating by means of visual languages, the author has chosen the drawing method of graphic storytelling (EISNER, 2004). This special form of communication exceeds the possibilities of other image-text literary genres.

Images are combined with the possibilities of narratives and thus expand their spectrum. This creates a richer potential for communication and interaction. The drawing, which was previously little known among this population group, was created in experimental approaches (EISNER, 2004).

\section{AN EXEMPLARY SEQUENCE/EXCERPT FROM THE MEMORY PROTOCOL OF FIELD RESEARCH}

Refugee Camp Smara; on the fourth day of February 2015; mornings, nine to eleven. Persons present: One interpreting teacher, twenty-four students, the author. On this fourth project day I am in a flat dry-brick building with a corrugated iron roof, no windows, electricity, running water. This classroom is equipped with blackboard, teaching desk, flat floor of terrazzo tiles. Indispensable and permanently present are sand deposits on the floor, furniture and equipment due to sand dust from outside. The central light source from the corrugated iron roof is a transparent plastic element, directly above the blackboard. In addition, light falls through the always open door. The blackboard and desk at the front of the room, next to the entrance area, are 


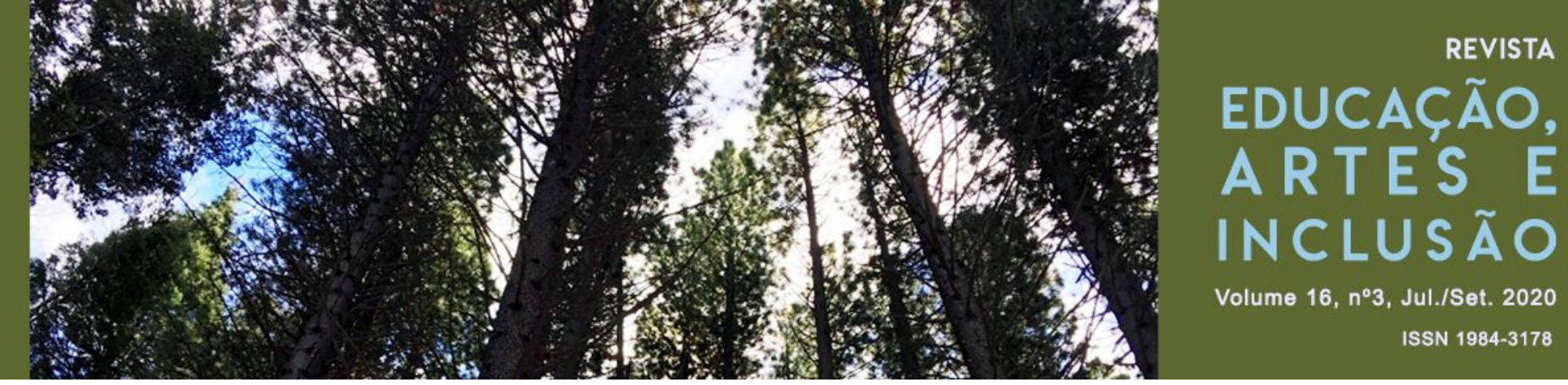

in the middle on the respective double tables; each child received a drawing sheet. The frontal alignment of the tables remained a known constant. The children thus worked at their usual places. First, first and last names as well as age should be written on the front or back of the drawing page. Some children first wrote the names of objects before they draw these objects. Without hesitation, they started drawing immediately. There was absolute silence and a concentrated atmosphere; without any admonition. Occasional photography on my part took place with a small digital camera and only rarely, without flash, without clicking noises. It was important to me to move around the classroom as quietly as possible in order to disturb image creation processes as little as possible and to be able to observe these activities more closely.

Motivating nods, participation and brief, mutually respectful interactions were the only and short forms of contact. There should be no interruption of the work process, no preference. "I do not praise! I do not criticize! I merely express my joy (Ich lobe nicht, ich tadele nicht, ich verleihe nur meiner Freude Ausdruck)". (LAVEN, 2006, p. 140). This bon mot of the reform pedagogical artist Franz Čižek comes to my mind in this situation. During the field contact, the works of the participating children are not commented on or evaluated; they are merely joyfully received. Motivation, support and participation should take place in a low-threshold way. The wax crayons in the bright colours are seldom preferred. These are not unknown to the children, yet there is obviously a high respect for using them. At a later stage of the unit these will also be used. The objects depicted by the children are mostly in bright colours. Trees, plants, animals and paths are mostly depicted in natural colours.

Those few children who work with pencils without exception show comparatively more detailed drawing results than those who also used crayons or oil crayons. Only when the painting utensils are exchanged is there whispering at some tables. Drawing is done slowly and very carefully. Single pencil strokes are drawn 


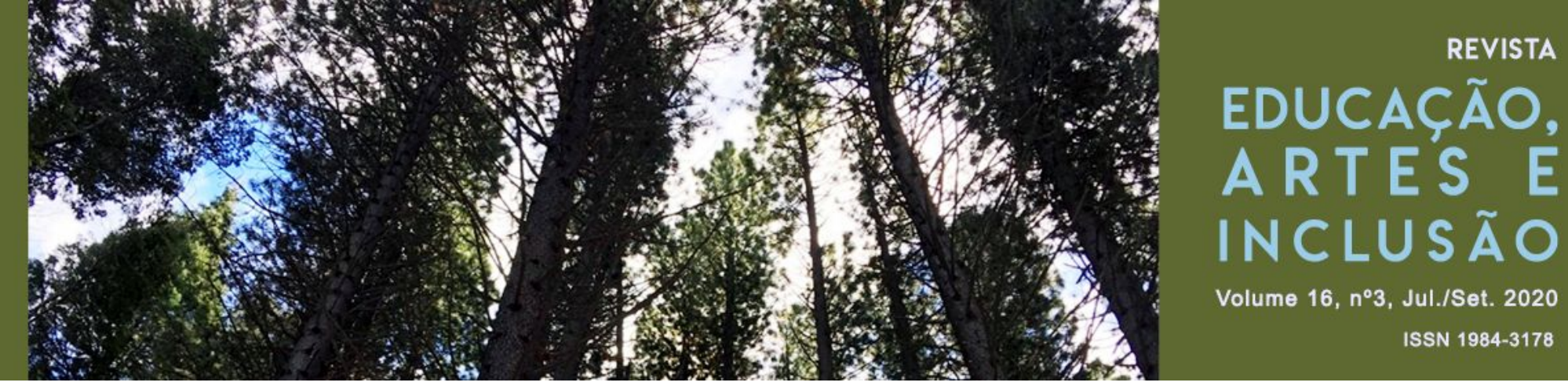

strongly and yet cautiously. Sometimes people pause, inspect the work of the people sitting next to me or look around aimlessly; sometimes I get patterned. At no point, however, do I feel like a foreign body or an instructor. There is a working atmosphere characterized by concentration, activity and contemplative silence. The crayons are rarely exchanged, rarely sharpened. There is never an erasure; no one asks for a new sheet. Spontaneously, the pencils on offer are used - the pencils that are closest to the original are usually chosen. It is noticeable that proportionality is rarely observed when drawing. About ten minutes before the end of the project time, the children are reminded to finish their work. When the time is up, the translator helps me to collect the drawings. Time frame: A total of two hours were spent on each of five consecutive days of lessons on the topic presented here. Most of the project days were held in a similarly concentrated atmosphere. Most of the time I had to resolutely ask several times at the end of the lessons to stop drawing, because the time frame is fulfilled.

\section{RECEPTION AND EVALUATION OF CHILDREN'S DRAWINGS}

Later on, the author reviewed the drawings several times at intervals in order to strengthen the intuitive image acquisition and understanding and to develop the signification of research-relevant, definable aspects. By using Graphic Story Telling, the use of writing is of interest; among other things, it acts as an explanatory signposting. In the context of this material interpretation, the focus is on aspects of narrative. No linguistic fixation of an interpretation that appears universally valid is intended. Rather, the pictures are asked what they tell about the lives of the young people in this specific environment or what they place in the - pictorial - space for interpretation. A far-reaching understanding of narration, as it flows into visual imagery, gives the life-related imagination - as a way of opening up the world - the space and appreciation. Narrative plays a particularly important role in the social and cultural interaction of the Sahrarouis, the formerly wandering Berber people of the 


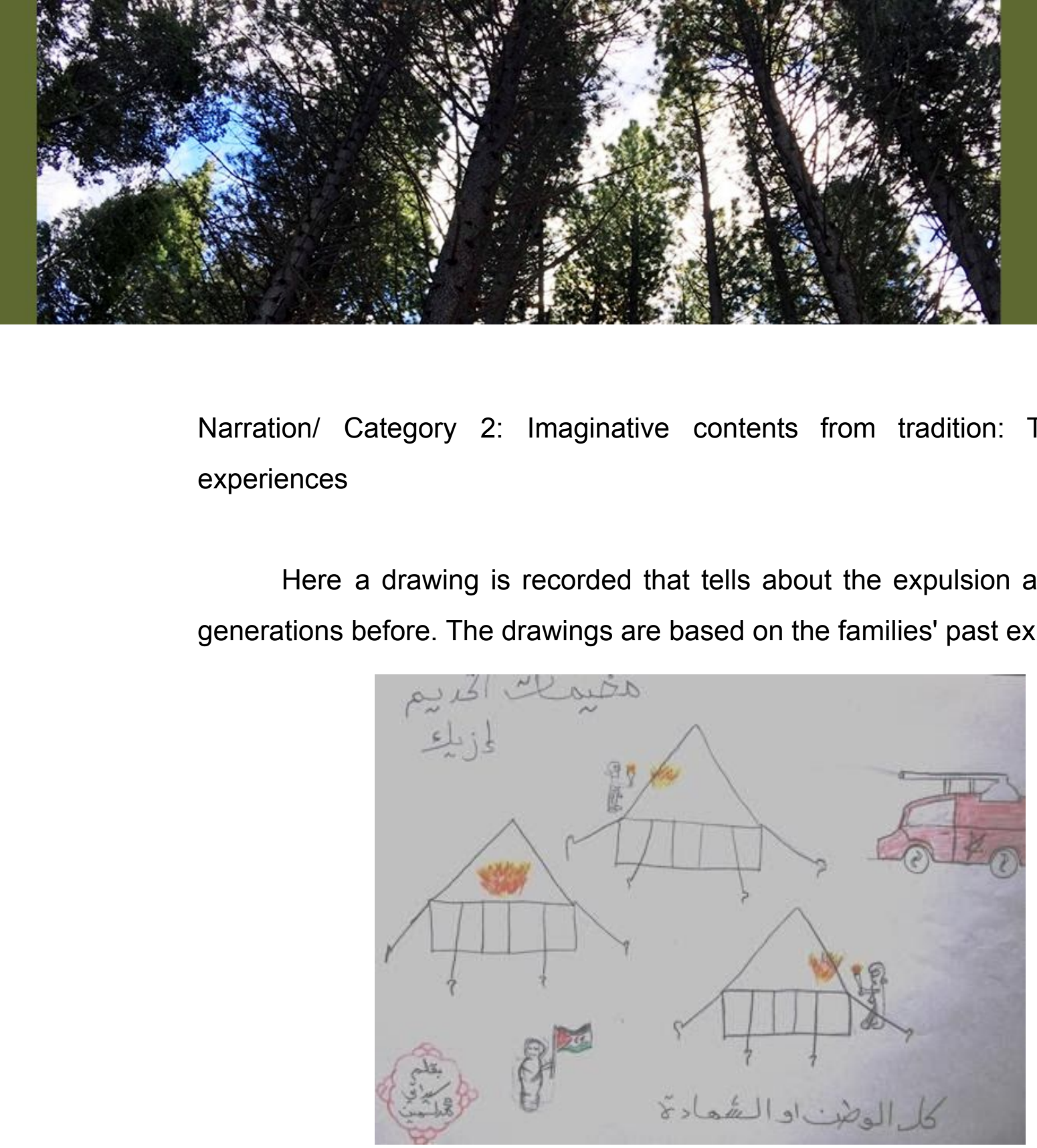

Narration/ Category 2: Imaginative contents from tradition: Transgenerational experiences

Fig. 06: Children's drawings: Extraordinary events in relation to persecution, flight $\odot$ Rolf Laven

Narration/ Category 2.1: Other aspects of the imagination: images of longing under positive and joyful omens

In this, image sections are captured that are not visible on site and actually do not exist, but which take place in the children's imagination and in their drawings. Among other things, these are football boots, the green football field, shower facilities, meadow, girls with blond hair. There is a content-related proximity to the pictures of longing, as they hang on the walls in the classroom. Possible sources could include experiences of transculturation. Due to the Saharaouis' significant focus on education and their contacts with educational institutions over decades, there is a traditional exchange across borders. In addition, the commonly known images are seen locally through television consumption. 


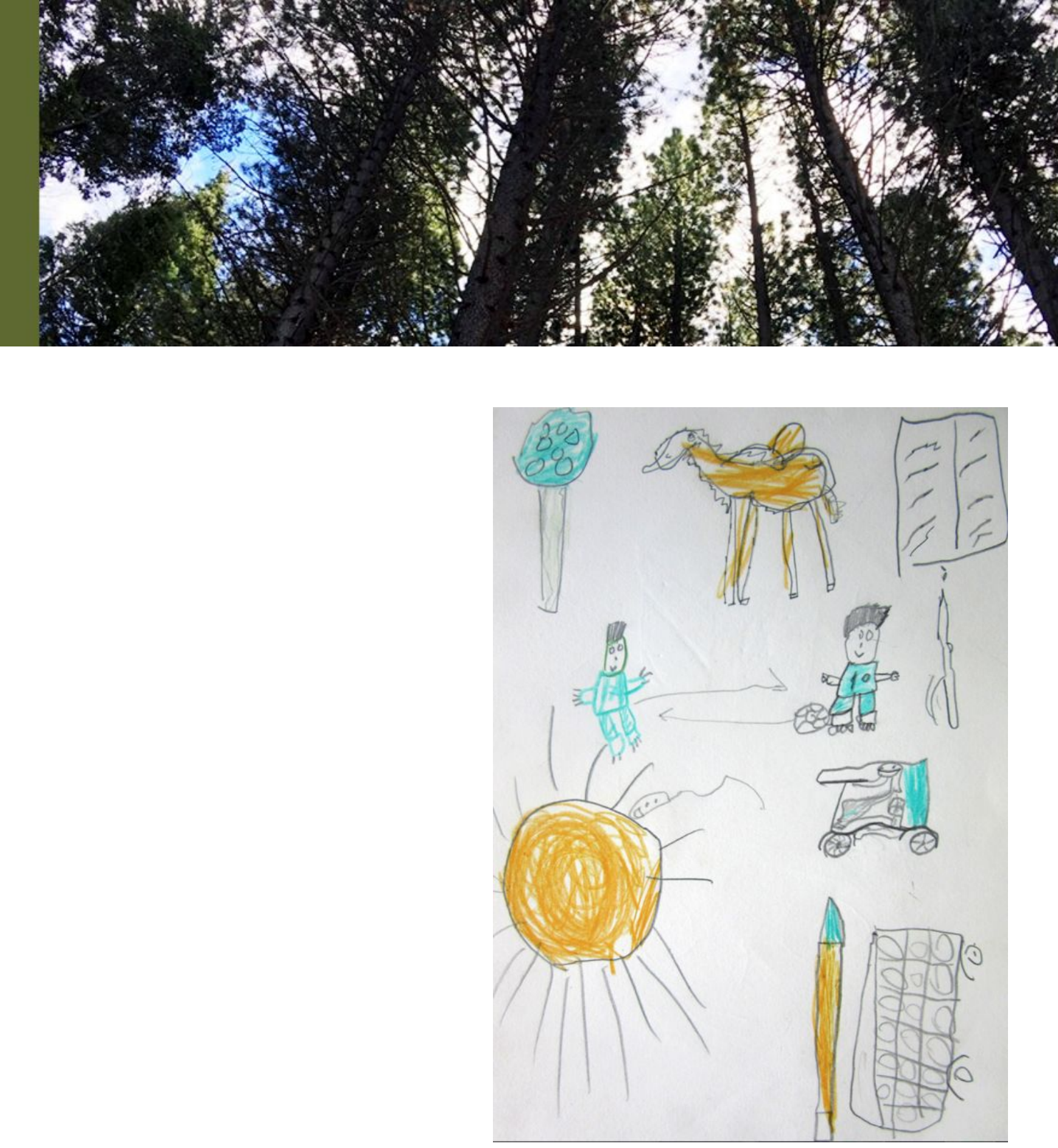

Fig. 08:- Children's drawing: narration about children's (experience) life: Imagination and Real-Thing Environment (c) Rolf Laven

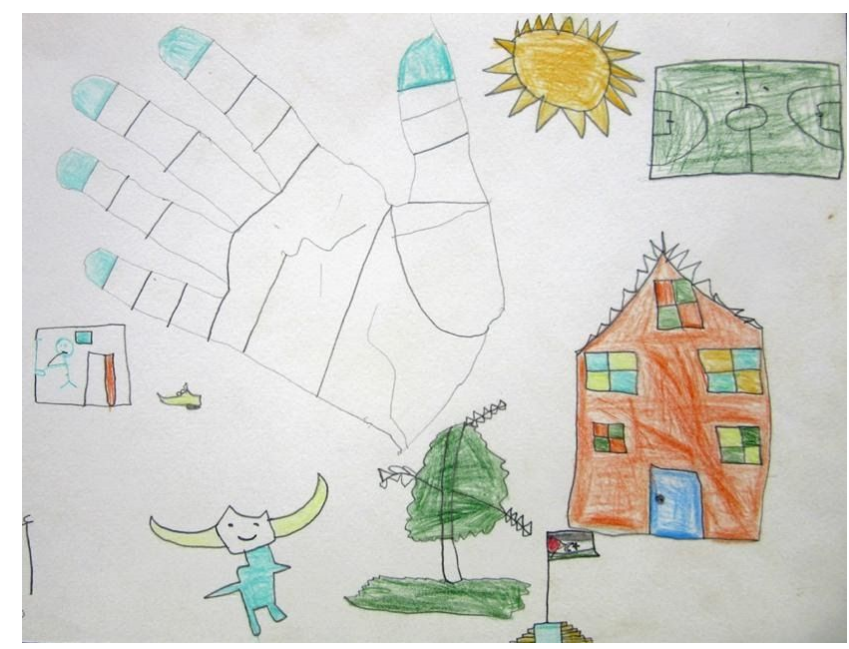

Fig. 09: Children's drawing: Imagined (house with pointed roof, green football field, tree) and real conditions (billy goat, house, tent, flag) are equally important in the picture ( Rolf Laven 


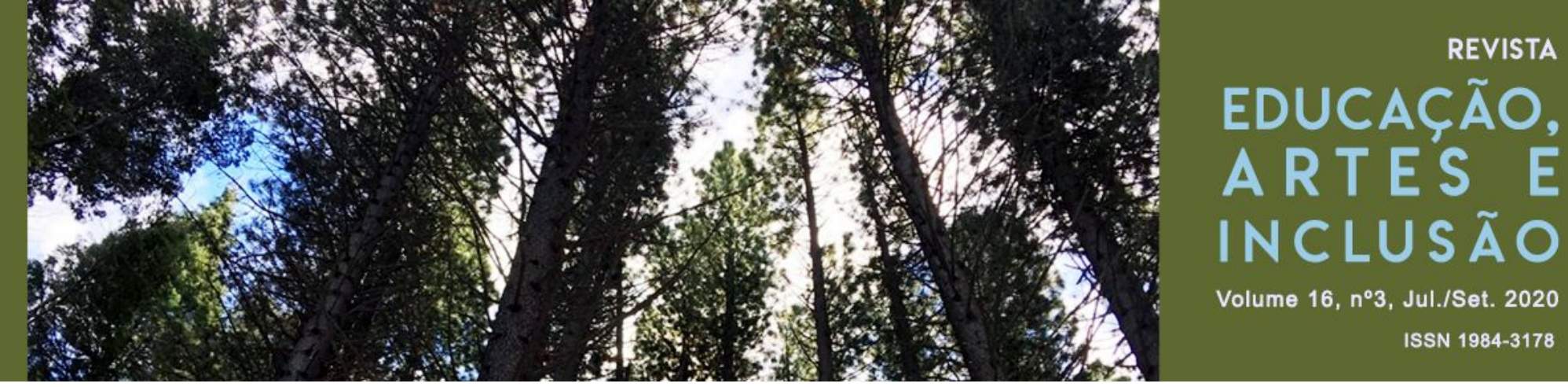

\section{ART EDUCATION DIDACTIC ASPECTS}

The exemplary implementation protocol conveys didactic aspects such as the analysis of the initial situation and the working environment and the fundamentally appreciative handling of these circumstances, but also the building of trust, the conveying of appreciation on a non-verbal level, the initiation of aesthetic experiences, the focus on the child's living environment and the creation of images.

This gave space to the experiences, everyday occurrences as well as the imaginations and ideals of the participating children. The transfer from traditional linguistic narration to visual and pictorial narrative took place. The previously unknown approach using graphic story telling was tested in an exemplary way. Once the drawings have been implemented, they generate numerous narrative and interactive possibilities, which may also be considered part of an educational experience. Drawing thus offers opportunities for communication. Font was partially integrated into the drawing image. It is thus part of the aesthetic experience. According to Michael Staiger (2012, p. 45), image and language are in any case inseparably linked in the narrative process - through the evocation of imaginary images; according to him, visual narrative is fundamentally essential in educational forms.

\section{REAL, IMAGINED, HANDED DOWN IN PICTORIAL TRANSFORMATION}

As can be seen from the presentation of categories, everyday experiences, actions and imaginations are formulated. In many cases - in addition to what might have actually been touched - the imaginary was depicted. These imaginations can be described, as the examples presented above show, partly as positive and joyful in the sense of images of longing and sometimes as frightening. These drawings make visible that numerous imaginations accompany the pictorial spaces of these children. According to Bettina Uhlig (2016, p. 181), "aspects flow into each other (Aspekte ineinander)" in the children's pictorial inventions or pictorial concepts: the 


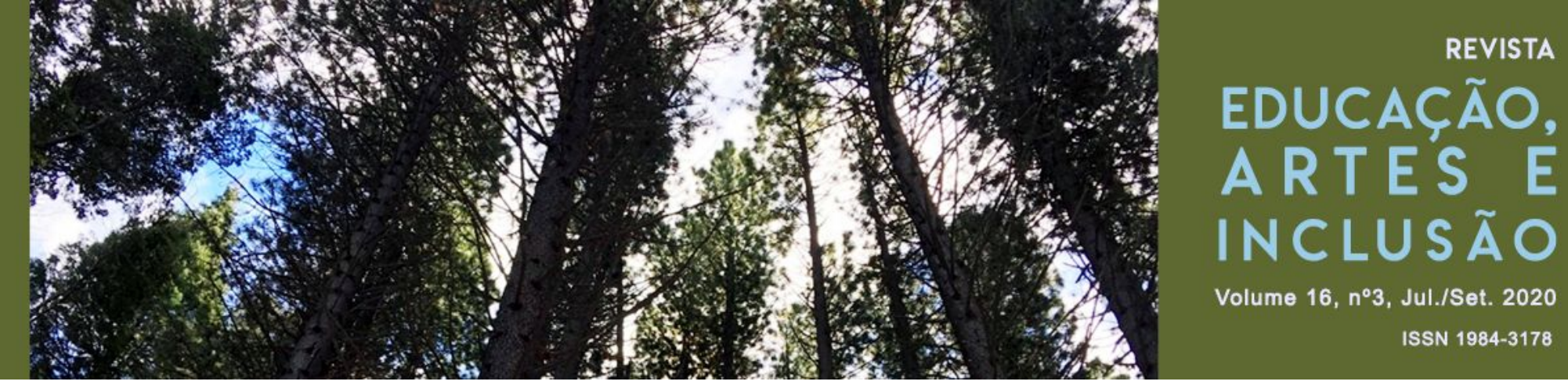

development of the pictorial memory and the pictorial worlds, the imagining, drawing or looking at pictures "are not forms of thought and action that can be separated from each other, but are closely interwoven (sind keine voneinander zu trennenden, sondern aufs Engste verwobene Denk- und Handlungsformen)" (UHLIG, 2016, p. 180). Such a (picture-conceptual) procedure would be "culturally generated and disposed of (kulturell erzeugt und disponiert)" (UHLIG, 2016, 175). In the children's drawings presented here, the imaginative childlike perspective of these adolescents who create these pictures is shown alongside representations that are comprehensible from a life-worldly, material point of view - without the author having intended it.

The present results underline that narration, as it "constitutively belongs to being human (konstitutiv dem Mensch-Sein zugehörig)", makes "the real and the fictitious equally accessible (das Wirkliche wie das Fiktive gleichermaßen zugänglich)" (UHLIG, 2016). These drawings are therefore to be understood as documents of child's perspective, world interpretation, here as the sum of real and imagined aspects. In this way, reference may be made to the vital ability of children to generate their ideas - possibly nourished by oral narration, transculturation, etc. on the basis of cultural disposition to their own pictorial narrative.

\section{SUMMARY}

The attention and appreciation of adults for the participating children and their pictures is understood by the author as an essential part of the project. The children themselves show great verve, commitment, conscientiousness and joy. The topics were chosen to ensure that what the children portray has to do with themselves, their lives and their individual impressions. Among other things, the real conditions of the social, material and spatial environment are depicted. Although the researcher had not in any way instructed the children to draw imaginary journeys, some of the children participating in the project depicted such content. These could be fed, among other things, by transculturalism or by the transmission of the immaterial 


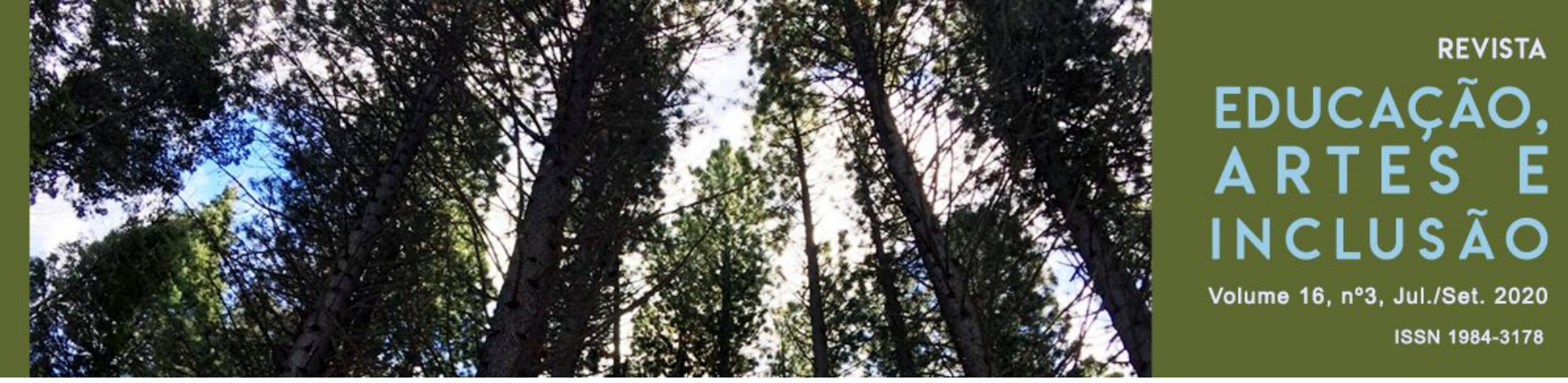

heritage. The children in this part of the Algerian Hamada, in whose habitat there are no trees, imagine touching fruit bearing trees.

\section{References}

ARENDT, Hannah. Macht und Gewalt. München: Piper, 1970.

EISNER, Will. Graphic Storytelling and Visual Narrative. 9th edition, Tamarac, 2004. Communicating about Graphic Novel - Series of Workshops. Universität Maribor, https://doaj.org/article/d54114147dd3407cb8bcc2cc45402c06. Acess Sept. 23, 2019.

FENNINGER, Erich and WEIDENHOLZER, Josef. Preface. In: FENNINGER, Erich. Von Freiheit träumen. Das Flüchtlingsleben der Westsahrauis. Wien: Mandelbaum, 2001.

GALEANO, Eduardo. Mauern - die Sahraouis dürsten nach Gerechtigkeit. 2006. http://www.oesg.ws/mediaarchiv/1/media/ Dokumente/Mauern_von_Eduardo_Galeano.pdf. Acess march, 20, 2020.

GALEANO, Eduardo. Walls. 2015. http://removethewall.org/walls-eduardo-galeano/ Acess march, 20, 2020.

HERRIGER, Norbert. Empowerment in der sozialen Arbeit. Eine Einführung. Stuttgart: Kohlhammer, 2014.

LAVEN, Rolf. Franz Čižek und die Wiener Jugendkunst. Wien: Schlebrügge, 2006.

MAROTZKI, K., W. and STOETZER, K. The Stories behind the Images (Die Geschichten hinter den Bildern. In: MAROTZK, K and NIESYTO, $\mathrm{H}$. (eds.) Image interpretation and image understanding. Methodical approaches from a social science, art and media education perspective. (Bildinterpretation und Bildverstehen. Methodische Ansätze aus sozialwissenschaftlicher, kunst- und medienpädagogischer Perspektive). Wiesbaden: VS Verlag für Sozialwissenschaften, 2006.

MAYRING, Philipp. Introduction to qualitative social research (Einführung in die qualitative Sozialforschung). Weinheim: Basel, 2002, p. 50-54.

STRÖTER-BENDER, Jutta and WOLTER, Heidrun. The UNESCO World Heritage Site in art lessons. Materials for Primary Schools, Vol.1 (Das Weltkulturerbe der UNESCO im Kunstunterricht. Materialien für die Grundschule, Band 1). Donauwörth, 2005.

UNO RESOLUTION S/RES 2414 (2018) ADOPTED AT THE 8246TH SESSION OF THE SECURITY COUNCIL ON 27.04.2018 
